Nevada

Environmental

Restoration

Project

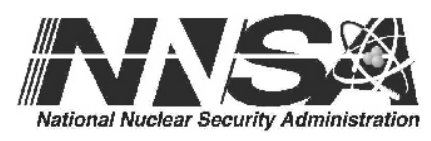

Addendum to the Closure Report for Corrective Action Unit 92: Area 6 Decon Pond Facility,

Nevada Test Site, Nevada

Controlled Copy No.:

Revision: 0

June 2007

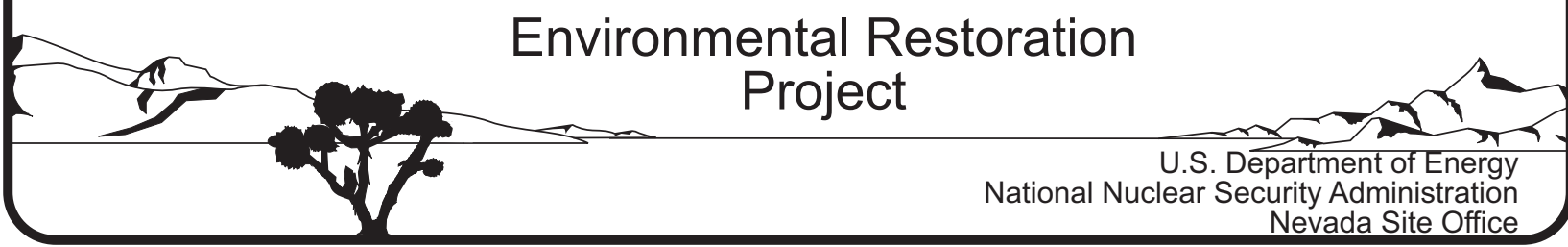




\title{
DISCLAIMER
}

Reference herein to any specific commercial product, process, or service by trade name, trademark, manufacturer, or otherwise, does not necessarily constitute or imply its endorsement, recommendation, or favoring by the United States Government or any agency thereof or its contractors or subcontractors.

This report has been reproduced directly from the best available copy.

Available for sale to the public from:

\author{
U.S. Department of Commerce \\ National Technical Information Service \\ 5285 Port Royal Road \\ Springfield, VA 22161-0002 \\ Telephone: (800) 553-6847 \\ Fax: (703) 605-6900 \\ E-mail: orders@ntis.gov \\ Online ordering: http://www.ntis.gov/ordering.htm
}

Available electronically at http://www.osti.gov/bridge.

Available for a processing fee to the U.S. Department of Energy and its contractors, in paper, from:

U.S. Department of Energy

Office of Scientific and Technical Information

P.O. Box 62

Oak Ridge, TN 37831-0062

Telephone: (865) 576-8401

Fax: (865) 576-5728

E-mail: reports@adonis.osti.gov 


\title{
ADDENDUM TO THE CLOSURE REPORT FOR CORRECTIVE ACTION UNIT 92: AREA 6 DECON POND FACILITY, NEVADA TEST SITE, NEVADA
}

\author{
U.S. Department of Energy \\ National Nuclear Security Administration \\ Nevada Site Office \\ Las Vegas, Nevada
}

Controlled Copy No.

Revision: 0

June 2007 
THIS PAGE INTENTIONALLY LEFT BLANK 


\section{ADDENDUM TO THE CLOSURE REPORT FOR CORRECTIVE ACTION UNIT 92: AREA 6 DECON POND FACILITY, NEVADA TEST SITE, NEVADA}

Kevin J. Cabble,

Federal Sub-Project Director

Industrial Sites Sub-Project

Approved By: SIGNATURE APPROVED

Date: June 21, 2007

John B. Jones,

Acting Federal Project Director

Environmental Restoration Project 
THIS PAGE INTENTIONALLY LEFT BLANK 


\section{PREFACE}

The following is an addendum to the Closure Report for Corrective Action Unit 92: Area 6 Decontamination Pond, Nevada Test Site, Nevada, DOE/NV/11718--306, dated April 1999.

This addendum includes Use Restriction Information forms and survey maps for CAS 06-04-01, Decon Pad Oil/Water Separator, and CAS 06-05-02, Decontamination Pond (RCRA), that were inadvertently left out of the Closure Report when it was published as a final document. 
Addendum to CAU $92 \mathrm{CR}$

Section: Preface

Revision: 0

Date: June 2007

\section{THIS PAGE INTENTIONALLY LEFT BLANK}


Addendum to CAU $92 \mathrm{CR}$

Section: UR Documentation

Revision: 0

Date: June 2007

\section{USE RESTRICTION DOCUMENTATION}


Addendum to CAU $92 \mathrm{CR}$

Section: UR Documentation

Revision: 0

Date: June 2007

THIS PAGE INTENTIONALLY LEFT BLANK 


\section{CAU Use Restriction Information}

CAU Number/Description: CAU 92: Area 6 Decon Pond Facility

Applicable CAS Numbers/Descriptions: CAS 06-04-01, Decon Pad Oil/Water Separator

Contact (organization/project): NNSA/NSO Federal Sub-Project Director

Surveyed Area (UTM, Zone 11, NAD 27, meters):

\begin{tabular}{|c|c|c|}
\hline UR POINTS & NORTHING & EASTING \\
\hline \hline North Corner & $4,088,001.5$ & $585,746.1$ \\
\hline East Corner & $4,087,997.1$ & $585,752.1$ \\
\hline South Corner & $4,087,992.9$ & $585,748.9$ \\
\hline West Corner & $4,087,997.4$ & $585,742.9$ \\
\hline
\end{tabular}

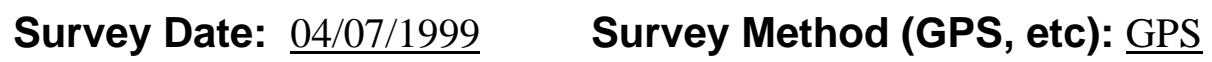

Site Monitoring Requirements: None

Required Frequency (quarterly, annually?): N/A

If Monitoring Has Started, Indicate last Completion Date: N/A

\section{Use Restrictions}

The future use of any land related to this Corrective Action Unit (CAU), as described by the above surveyed location, is restricted from any DOE or Air Force activity that may alter or modify the containment control as approved by the state and identified in the CAU Closure Report or other CAU documentation unless appropriate concurrence is obtained in advance.

Comments: See the Closure Report for additional information on the condition of the site(s) and any monitoring and/or inspection requirements.

Submitted By: Date:

cc with copy of survey map (paper and digital (dgn) formats): CAU Files ( 2 copies) 


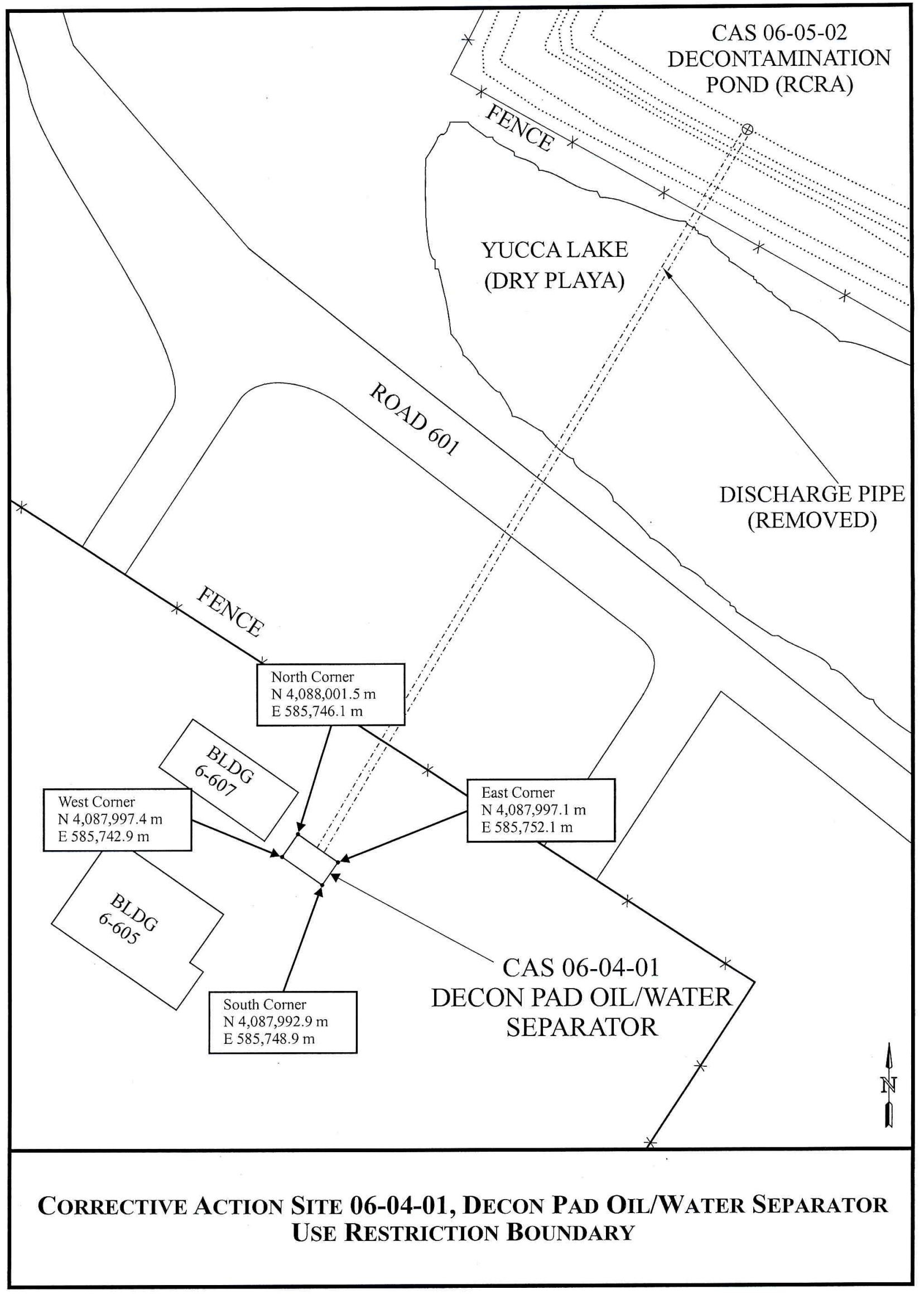




\section{CAU Use Restriction Information}

CAU Number/Description: CAU 92: Area 6 Decon Pond Facility

Applicable CAS Numbers/Descriptions: CAS 06-05-02, Decontamination Pond (RCRA)

Contact (organization/project): NNSA/NSO Federal Sub-Project Director

Surveyed Area (UTM, Zone 11, NAD 27, meters):

\begin{tabular}{|c|c|c|}
\hline UR POINTS & NORTHING & EASTING \\
\hline \hline North Corner & $4,088,239.69$ & $585,852.84$ \\
\hline East Corner & $4,088,188.71$ & $585,929.13$ \\
\hline South Corner & $4,088,111.53$ & $585,877.57$ \\
\hline West Corner & $4,088,162.50$ & $585,801.28$ \\
\hline
\end{tabular}

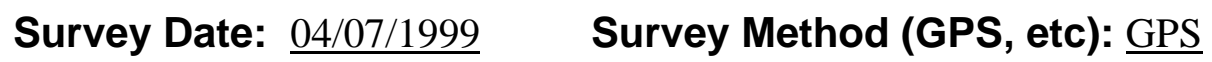

Site Monitoring Requirements: Visual Inspections

Required Frequency (quarterly, annually?): Quarterly

If Monitoring Has Started, Indicate last Completion Date: $\underline{03 / 29 / 2007}$

\section{Use Restrictions}

The future use of any land related to this Corrective Action Unit (CAU), as described by the above surveyed location, is restricted from any DOE or Air Force activity that may alter or modify the containment control as approved by the state and identified in the CAU Closure Report or other CAU documentation unless appropriate concurrence is obtained in advance.

Comments: See the Closure Report for additional information on the condition of the site(s) and any monitoring and/or inspection requirements.

Submitted By: Date:

cc with copy of survey map (paper and digital (dgn) formats): CAU Files ( 2 copies) 


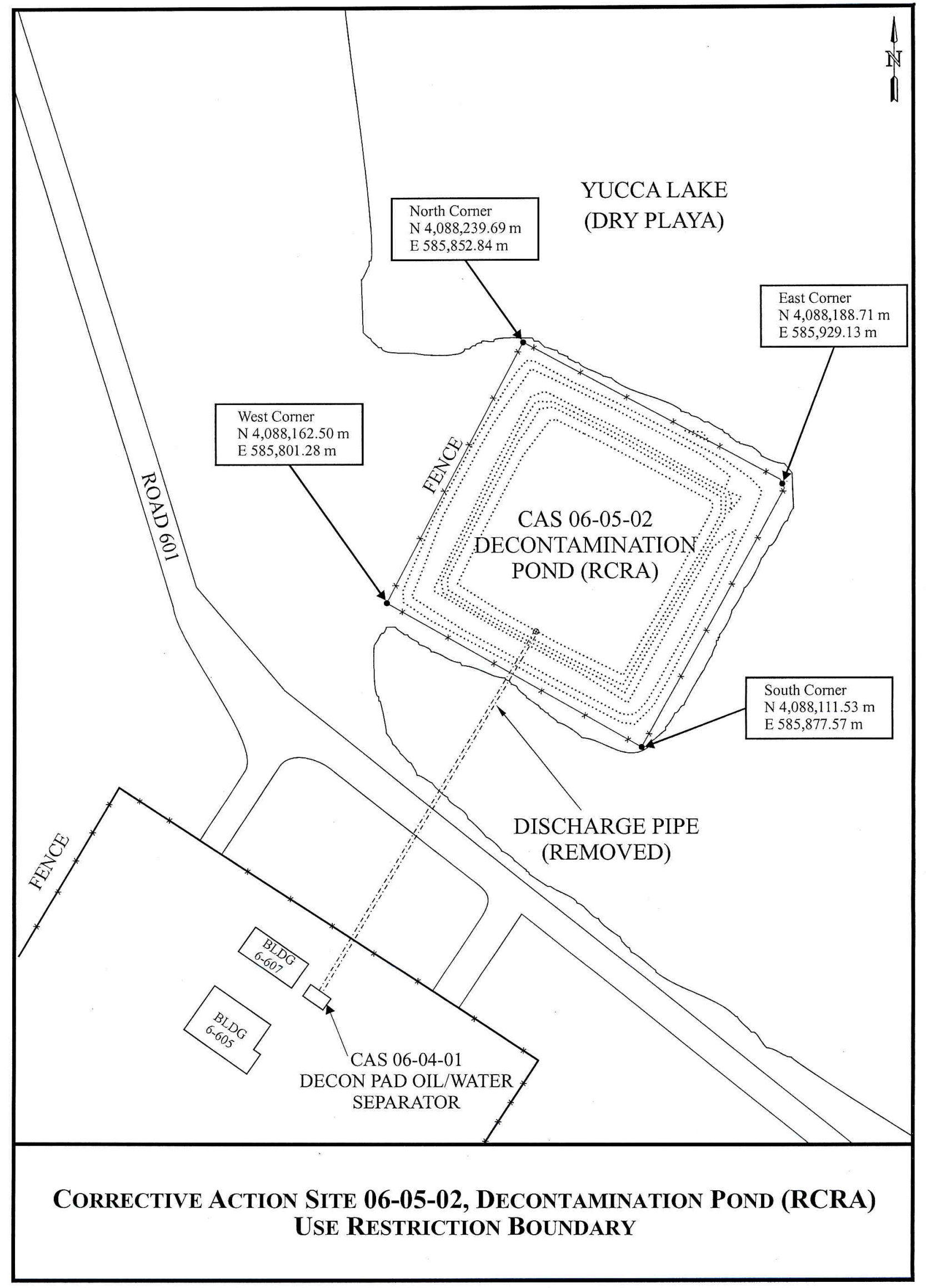


Addendum to CAU $92 \mathrm{CR}$

Section: Library Distribution List

Revision: 0

Date: June 2007

\section{LIBRARY DISTRIBUTION LIST}


Addendum to CAU $92 \mathrm{CR}$

Section: Library Distribution List

Revision: 0

Date: June 2007

THIS PAGE INTENTIONALLY LEFT BLANK 
U.S. Department of Energy

National Nuclear Security Administration

Nevada Site Office

Technical Library

P.O. Box 98518, M/S 505

Las Vegas, NV 89193-8518

U.S. Department of Energy

Office of Scientific and Technical Information

P.O. Box 62

Oak Ridge, TN 37831-0062

Southern Nevada Public Reading Facility

c/o Nuclear Testing Archive

P.O. Box 98521, M/S 400

Las Vegas, NV 89193-8521

Manager, Northern Nevada FFACO

Public Reading Facility

c/o Nevada State Library \& Archives

Carson City, NV 89701-4285
1 (Uncontrolled, electronic copy)

1 (Uncontrolled, electronic copy)

2 (Uncontrolled, electronic copies)

1 (Uncontrolled, electronic copy) 
Addendum to CAU $92 \mathrm{CR}$

Section: Library Distribution List

Revision: 0

Date: June 2007

THIS PAGE INTENTIONALLY LEFT BLANK 